\title{
Ionizing Radiation Induces Cytokines, MMP-1, TIMP-1 and Supresses Type I Collagen mRNA Expressions in Human Gingival Fibroblasts
}

\author{
Guler YAVAS ${ }^{1}$, Cagdas YAVAS ${ }^{2}$, S. Buket BOZKURT ${ }^{3}$, Ozlem ATA ${ }^{4}$, Sema HAKKI \\ ${ }^{1}$ Selcuk University, Faculty of Medicine, Department of Radiation Oncology \\ ${ }^{2}$ Konya Training and Research Hospital, Department of Radiation Oncology \\ ${ }^{3}$ Selcuk University, Faculty of Dentistry, Research Centre \\ ${ }^{4}$ Selcuk University, Faculty of Medicine, Department of Medical Oncology \\ ${ }^{5}$ Selcuk University, Faculty of Dentistry, Department of Periodontology, Konya, TURKEY
}

\begin{abstract}
We aimed to evaluate the effects of ionizing radiation on the proliferation of gingival fibroblasts and the expressions of proinflammatory cytokines and matrix metalloproteinase-1 (MMP-1), tissue inhibitor of matrix metalloproteinase-1 (TIMP-1) and type I collagen (type I Col) mRNA transcripts. Gingival fibroblasts were treated with radiation doses as follows; 0.5 Gy, 1 Gy, 2 Gy, 4 Gy, 6 Gy, and 8 Gy. Expression of interleukin (IL)-1B, IL-6, IL-8 and, MMP-1, TIMP-1 and of type I Col mRNA transcripts in human gingival fibroblasts was determined by quantitative polymerase chain reaction (PCR) analysis. Morphology of gingival fibroblasts was evaluated using inverted microscope. lonizing radiation decreased cell proliferation $(\mathrm{p}<0.05)$ compared to the control group. Expressions of IL-1 B, IL-6 and IL-8 were stimulated at the highest dosage of radiation $(\mathrm{p}<0.001)$. In parallel to proinflammtory cytokines, MMP-1 and TIMP-1 mRNA expressions were elevated in response to higher dosage of radiation $(\mathrm{p}<0.001)$. Radiation suppressed type I Col mRNA expression in response to all doses at 24 hrs $(p<0.001)$. In addition to basal epithelial cells of the oral mucosa, gingival fibroblasts have an important role in the pathogenesis of oral mucositis. Results of this study may help to clarify the role of gingival fibroblasts in radiation induced oral mucositis.
\end{abstract}

Keywords: Gingival fibroblast, lonizing radiation, Oral mucositis, Proinflammatory cytokines

\section{ÖZET}

İyonizan Radyasyon İnsan Gingival Fibroblastlarında Sitokinleri, MMP-1, TIMP-1'i İndükler ve Tip I mRNA Ekspresyonunu Süprese Eder

İyonizan radyasyonun gingival fibroblastların proliferasyonlarına, gingival fibroblastlardan proinflamatuar sitokinlerin ekspresyonu ve matriks metaloproteniaz -1 (MMP-1), matriks metaloproteinaz doku inhibitörü-1 (TIMP-1) ve tip I kollajen (tip I Col) mRNA transkriptlerine olan etkilerini değerlendirmeyi amaçladık. Gingival fibroblastlar farklı radyasyon dozları ile tedavi edildi: 0.5 Gy, 1 Gy, 2 Gy, 4 Gy, 6 Gy ve 8 Gy. Insan gingival fibroblastlarındaki interlökin (IL)- 1B, IL-6, IL-8 ekspresyonu ve MMP-1, TIMP-1 ve tip I Col mRNA transkriptleri polimeraz zincir reaksiyonu (PCR) analizi ile tanımlandı. Gingival fibroblastların morfolojisi inverted mikroskop ile değerlendirildi. Kontrol grubu ile karşılaştırılığında iyonizan radyasyon hücre proliferasyonunu azalttı ( $p<0.05)$. IL-1B, IL-6 ve IL-8'in ekspresyonu en yüksek doz radyasyon ile stimüle oldu $(p<0.001)$. Proinflamatuar sitokinlere paralel olarak, MMP-1 ve TIMP-1'in mRNA ekspresyonları yüksek doz radyason ile arttı $(p<0.001)$. Radyasyonun tüm dozlarda 24. saatte tip I Col mRNA ekspresyonunu süprese ettiği gözlendi ( $p<0.001)$. Oral mukozadaki bazal epitel hücrelere ek olarak gingival fibroblastlar da oral mukozitin patogenezinde önemli bir rol oynamaktadır. Bu çalışmanın sonuçları gingival fibroblastların radyasyona bağı gelişen oral mukozitteki rolünü açıklamaya yardımcı olabilir.

Anahtar Kelimeler: Gingival fibroblast, lyonizan radyasyon, Oral mukozit, Proinflamatuar sitokinler 


\section{INTRODUCTION}

Radiation therapy (RT) and chemotherapy are the most widely used treatment options in the management of head and neck cancer. Although these treatments are employed to improve quality of life, they are associated with several side effects. ${ }^{1}$ Oral mucositis, which is commonly observed in patients with head and neck region tumors, is one of the inevitable side effects of RT. Incidence of oral mucositis was especially high in patient: (i) with primary tumors in the oral cavity, oropharnyx or nasopharynx; (ii) who received concurrent chemotherapy; (iii) who received a total dose of radiation more than $50 \mathrm{~Gy}$; and (iv) who was treated with altered fractionation radiation schedules. $^{2}$

For years, radiation-induced mucositis had been thought to based on the direct injury to rapidly dividing cells of the basal epithelium. However over the past decade, this concept has been replaced by the realization that mucositis is not only from the consequence of direct cell injury but also from the consequences of a series of complex biological events arising in the cells and tissues of the submucosa. ${ }^{3,4}$

Sonis has described the pathobiologic progression of mucositis in five phases. ${ }^{5}$ The first phase of mucositis is termed as "initiation phase". In this phase ionizing radiation and cytotoxic drugs directly injure DNA and cause strand breaks resulting in clonogenic death of basal epithelial cells. As a result of tissue damage reactive oxygen species (ROS) and consequent oxidative stress develop. ROS induce two important transcription factors, nuclear factor-kB (NF-kB) and STAT3, both of which provide the activation of genes that are associated with tissue-damage mediating cytokines.

During the second phase, which is also known as primary damage response phase, a number of significant genes are expressed, including those controlling the production of proinflammatory cytokines, endothelial growth factors, and cycloxoygenases. Finally, damage to connective tissue fibrin leads to the activation of matrix metalloproteinases (MMPs). In the next phase, signal amplification phase, many of the mediators generated during the primary damage response provide positive feedback to result in a growing cascade of damaging mediators.

The ulcerative phase is characterized by a robust infiltrate within which macrophages, neutrophils, and mast cells. The cell wall products released from the bacteria on the ulcer surface penetrate the disrupted mucosa and stimulate infiltrating macrophages to produce additional proinflammatory cytokines. Proinflammatory cytokines especially interleukin (IL)$1 \beta, \mathrm{IL}-6$ and tumor necrosis factor (TNF) have been suggested to play a key role in the development of oral mucositis. During the final phase of mucositis, healing occurs. Within the 4 weeks after the last dose of radiation healing is generally complete. The majority of the cases of oral mucositis heal spontaneously. ${ }^{4,5}$

Gingival fibroblasts are the most common cell in the periodontal connective tissue. ${ }^{6,7}$ The role of this cell is to produce structural connective tissue proteins like collagen, elastic fibers as well as glycoproteins and glycoseaminoglycans. The major roles of the gingival fibroblasts are defined as to produce and modify the extracellular matrix and to help maintaining tissue integrity and homeostasis. ${ }^{8}$ Also these cells secrete a variety of immunoregulatory cytokines and chemical mediators upon stimulation with physiological and pathological impulse. ${ }^{9}$

Despite its importance, relatively little is known about the pathobiology of radiation-induced oral mucositis. Moreover the role of gingival fibroblasts in radiation-induced oral mucositis has not been clearly defined yet. In the current study we aimed to evaluate the effects of ionizing radiation on the proliferation of gingival fibroblasts and proinflammatory cytokines and MMP-1, tissue inhibitor of matrix metalloproteinase-1 (TIMP-1) and type I collagen (type I Col) mRNA expressions of gingival fibroblasts.

\section{MATERIALS AND METHODS}

\section{Cell Culture}

Gingival fibroblasts were isolated from human gingival connective tissue of systemically healthy individuals. The human gingival fibroblasts (HGF) were obtained from samples of gingiva without inflammation, removed for crown lengthening purposes in maxillary anterior region. All patients gave informed consent before providing the samples. This protocol was approved by Ethics Committee of the Selcuk University Faculty of Dentistry. Gingival tissues cut into small pieces, rinsed with biopsy media, placed in tissue culture dishes and were incubated in biopsy medium in a humidified atmosphere of $95 \%$ air and $5 \% \mathrm{CO}_{2}$ at $37^{\circ} \mathrm{C}$ overnight. The following day, biopsy medium (Dulbecco's Modified Minimal Essential 
Table 1. Synthetic oligonucleotide primers for real time PCR.

\begin{tabular}{|c|c|}
\hline Primers & Sequences \\
\hline \multirow[t]{2}{*}{ Type I Col } & F5'-GCAACATTGGATTCCCTGGACC-3' \\
\hline & R5'-GTTCACCCTITCTCCCTTGCC-3' \\
\hline \multirow[t]{2}{*}{ MMP-1 } & F 5'-GATGGGAGGCAAGTTGAAAA-3’ \\
\hline & R 5'-CTGGTTGAAAAGCATGAGCA-3’ \\
\hline \multirow[t]{2}{*}{ TIMP-1 } & F 5'-GCTTCTGGCATCCTGTTGT-3` \\
\hline & R 5-TाTGCAGGGGATGGATAAAC-3’ \\
\hline \multirow[t]{2}{*}{ GAPDH } & F 5'- ACCACAGTCCATGCCATCAC-3' \\
\hline & R 5'-TCCACCACCCTGTTGCTGTA-3' \\
\hline
\end{tabular}

All sequences are obtained from human and listed 5' - 3' sequences of primers. GAPDH: glyceraldehyde-3- phosphate dehydrogenase MMP-1: matrix metalloproteinase-1; TIMP-1: tissue inhibitor of matrix metalloproteinase-1; Type I Col: type I collagen.

Medium (DMEM) with \% 10 Fetal Bovine Serum (FBS), $250 \mu \mathrm{g} / \mathrm{ml}$ gentamisin sülfat, $5 \mu \mathrm{g} / \mathrm{ml}$ amfoterisin B) was replaced with culture medium (DMEM with $10 \%$ FBS, 100 units $/ \mathrm{ml}$ penicillin, $100 \mu \mathrm{g} / \mathrm{ml}$ streptomycin). After reaching confluency, cells were passaged with $0.25 \%$ trypsin (Biological Industries, Kibbutz Beit Haemek, Israel) and $0.1 \%$ ethylene diaminotetraacetic acid (EDTA). HGF were used between the 4th and 6th passage for all experiments.

\section{Study design}

Cells were treated with increasing radiation doses as follows: control group (untreated); 0.5 Gy, $1 \mathrm{~Gy}, 2$ Gy, 4 Gy, 6 Gy, 8 Gy.

RT was applied with $6 \mathrm{MV}$ photon beams (Clinac DHX linear accelerator). Irradiation was performed in one direction, from anterior to posterior, and the dose was prescribed to $1.5 \mathrm{~cm}$ depth with source-axis distance (SAD) technique. To provide con $\neg$ tour regularity, $1 \mathrm{~cm}$ elasto-gel bolus was used.

\section{Morphology of gingival fibroblasts}

In order to assess the gingival fibroblasts morphology at the ultra-structural level, images of gingival fibroblasts were taken after increasing doses of radiation using inverted microscope.

\section{Cell proliferation}

In order to test the impact of radiation on HGF proliferation, cells were plated to 24-well-plate and treated with different doses of radiation as described above. Cells were detached by trypsin containing $0.025 \%$ EDTA. Cell numbers were determined and viability was assessed by trypan blue exclusion at $24 \mathrm{hrs}$.

\section{RNA Isolation}

To determine gene expression, gingival fibroblasts were plated in T25 cell culture flasks (Corning, NY, USA) at $25 \times 10^{3} \mathrm{cells} / \mathrm{cm}^{2}$ and treated after 24 hours as described above. Total RNA was isolated at 24 hours after radiation using a monophasic solution of phenol and guanidine isothiocyanate. RNA concentration was quantified at $260 \mathrm{~nm}$ by nanodrop and RNA samples were stored at $-80^{\circ} \mathrm{C}$.

\section{cDNA synthesis and real-time quantitative RT- PCR}

For real time polymerase chain reaction (RT-PCR) analysis, cDNA was synthesized from $1.0 \mu \mathrm{g}$ of total RNA with a cDNA synthesis kit (High Capacity RNA-to-cDNA kit) (Applied Biosystems, Foster City, USA) for RT-PCR. From the resulting cDNA product, $1.0 \mu \mathrm{l}$ was used per $25 \mu \mathrm{l}$ final reaction volume in the Stratagene MX3000P. PCR reactions were carried out with the Brilliant SYBR Green QPCR Master Mix kit (Stratagene, TX, USA), in a total volume of $25 \mu \mathrm{l}$.

For real-time PCR, we used primers and TaqMan probes for IL-1ß (Hs00174097_m1), IL-6 (Hs00985641_m1), IL-8 (Hs99999034_m1) and glyceraldehyde-3- phosphate dehydrogenase (GAP- 


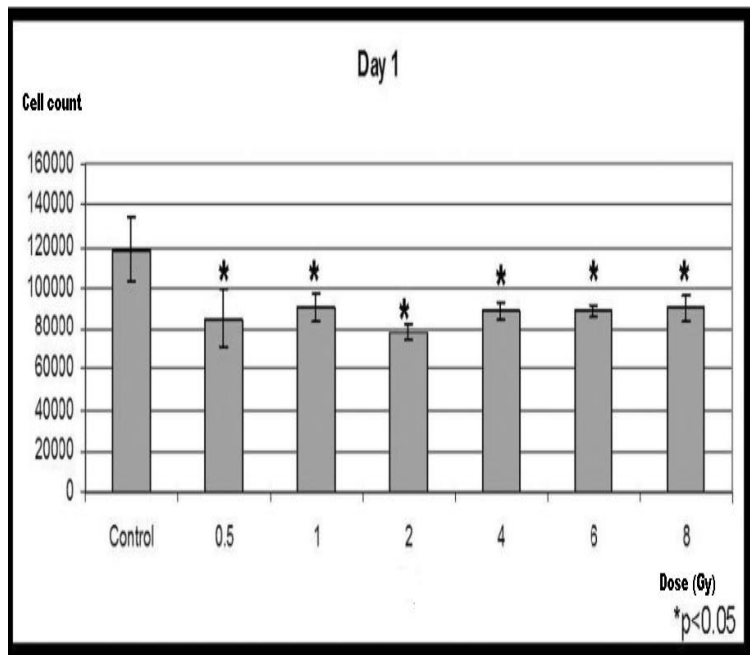

Figure 1. Gingival fibroblast proliferation at 24 hours. The proliferation of gingival fibroblasts was decreased significantly in all irradiated group compared with control group $(p<0.05)$.

DH) (Hs02758991_g1) obtained from Applied Biosystems. Primers were designed by DNA-Star design software. A BLAST search of GenBank was performed on the primer sequences to ensure specificity. GAPDH served as a housekeeping/reference gene for normalization. The primer sequences are described in Table 1.The amplification profile for IL-1ß, IL-6, IL-8 and GAPDH used on the Strategene MX3000P was: $95 / 10$ minutes; $95 / 15$ second: 60/60 second (temperature $(\mathrm{oC}) /$ time) and 40 cycles. The amplification profile for MMP-1, TIMP-1, GAPDH used on the Strategene MX3000P was: $94 / 3$ minutes; $94 / 45$ second: 55/50 second: 72/60 second: 72/10 minutes (temperature ${ }^{\circ} \mathrm{C} /$ time) and 40 cycles. Samples were normalized for the expression of the housekeeping gene GAPDH, which were not affected by the experimental conditions, by calculating the $\Delta \mathrm{Ct}$ (Ct housekeeping gene - $\mathrm{Ct}$ gene of interest), and the expression of different genes was expressed as $2-\Delta \mathrm{Ct}$. Triplicates were performed for each experimental point. Quantitative polymerase chain reaction (Q-PCR) experiments were repeated 3 times. Quantitative RT-PCR experiments were repeated 2 times.

\section{Statistical Analysis}

One-way analysis of variance (ANOVA) and Tukey HSD multiple comparison tests were used for proliferation experiments and gene expressions. The data are represented as mean \pm standard deviation. A value of $\mathrm{p}<0.05$ was considered to be statistically significant.

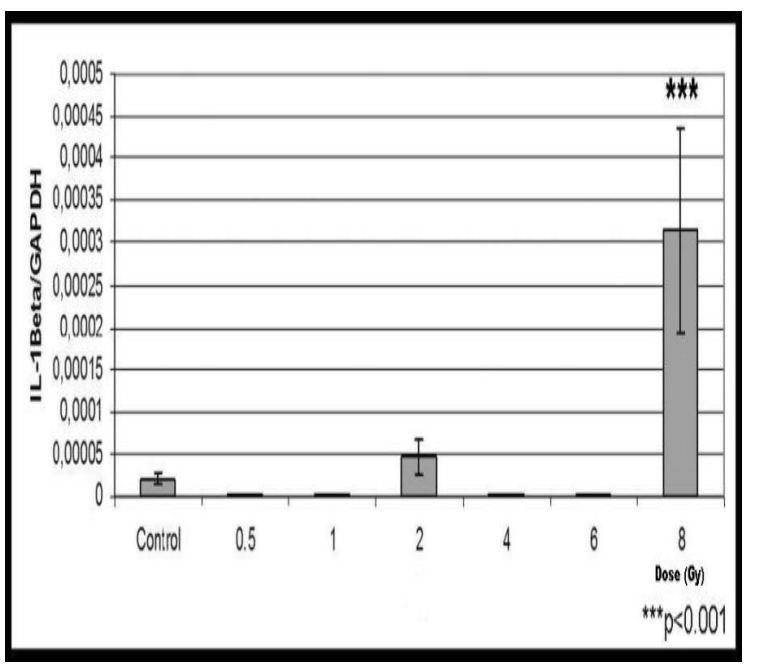

Figure 2a. Levels of mRNA of IL-1B, after different doses of RT. In 8 Gy radiotherapy group IL-1B level was increased at significant level $(p<0.001)$ compared to both control group and lower doses of radiotherapy groups.

\section{RESULTS}

\section{Cell morphology and proliferation}

There was no morphological change in normal spindle shape of gingival fibroblasts after RT. When compared to the control group, cell proliferation was decreased in all irradiated groups at 24 hours of RT $(\mathrm{p}<0.05)$ (Figure 1).

mRNA expressions of cytokines and MMP-1, TIMP-1 and Type I Collagen

\section{$I L-1 \beta, I L-6$ and $I L-8$ mRNA expressions}

We observed statistically significant up-regulation for all cytokines in the 8 Gy RT group when compared to control group $(\mathrm{p}<0.001)$. No difference was noted in the other groups (Figure 2a, b, and c)

\section{MMP-1 and TIMP-1 MRNA expression}

In parallel to cytokine expressions, MMP-1 and TIMP-1 mRNA expressions were elevated in response to highest dose $(8 \mathrm{~Gy})$ of radiation $(\mathrm{p}<0.001)$. MMP-1 transcript was also increased in the cells treated with 0.5 Gy RT ( $<<0.001$ ) (Figure 3a). The mRNA level of TIMP-1 was also elevated in 0.5 and 6 Gy groups $(p<0.01)$ (Figure $3 b)$.

\section{Type I Collagen mRNA expression}

Type I Col mRNA expressions were decreased in all the RT groups at 24 hrs $(\mathrm{p}<0.001)$. The levels of decrements were independent of the RT doses (Fig- 


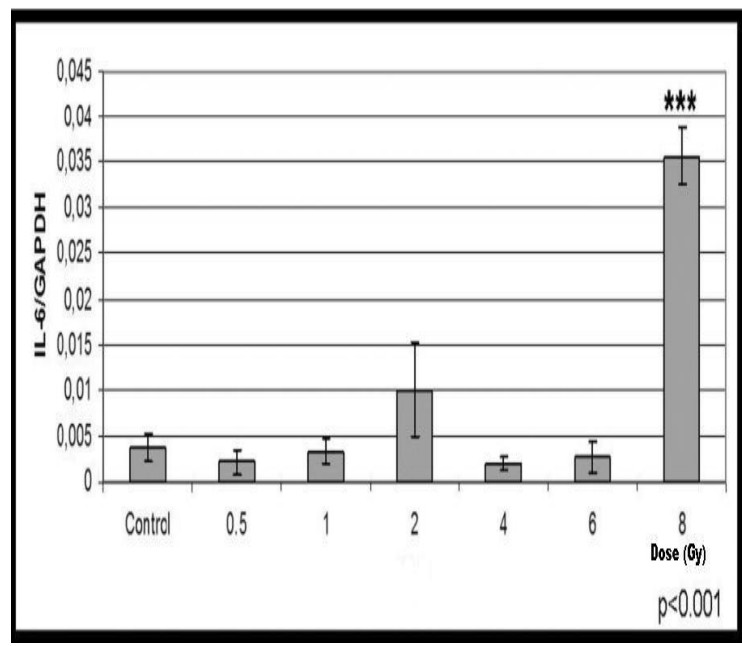

Figure $\mathbf{2 b}$. Levels of mRNA of IL-6 after different doses of RT. In 8 Gy radiotherapy group IL-6 level was increased at significant level $(p<0.001)$ compared to both control group and lower doses of radiotherapy groups.

ure 3c). All doses of RT strongly down-regulated the Type I Col mRNA expressions.

\section{DISCUSSION}

Despite advances in the field of the radiation oncology, acute oral mucositis has still been a major dose limiting side effect in head and neck cancer patients treated with RT. The incidence of oral mucositis has been reported as high as $90 \%$ in patients with head and neck cancer. 10 We should clarify the exact mechanism of radiation-induced oral mucositis, in order to minimize the development of oral mucositis in

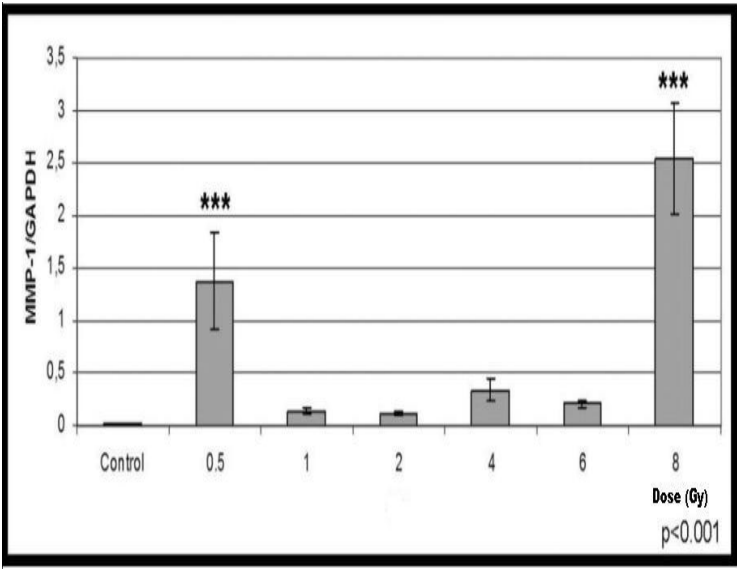

Figure 3a. Levels of MMP-1 after different doses of RT. In both 0.5 and 8 Gy groups MMP-1 levels increased which were statistically significant $(p<0.001)$.

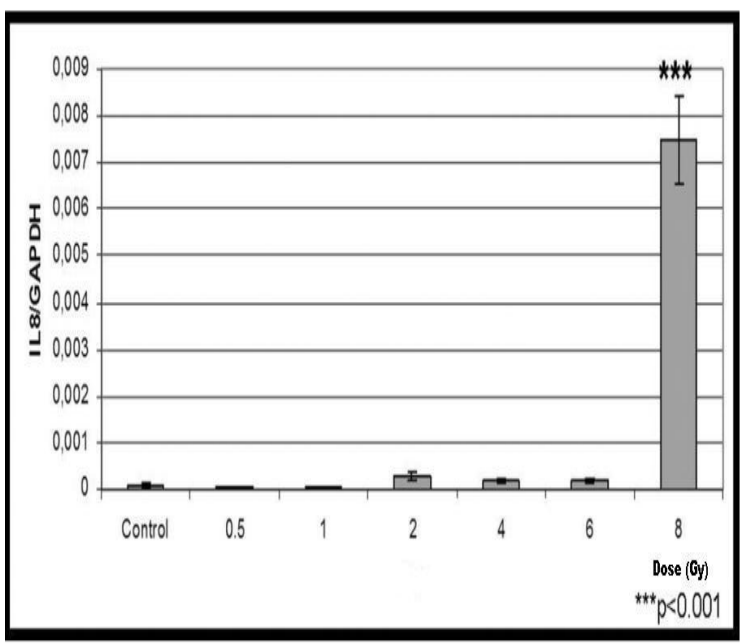

Figure 2c. Levels of mRNA of IL-8 after different doses of RT. In parallel to IL-1B and IL-6 levels, IL-8 levels increased in the highest doses of radiotherapy group $(p<0.001)$.

patients with head and neck cancer who underwent radiation treatment. Also better understanding of the biological events and the mediators of this damage is required in order to target appropriate treatment strategies.

It is well known that epithelial cells of the oral mucosa play a key role in the generation of oral mucositis. For many years, the primary role of the extracellular matrix (ECM) was believed to provide structural organization to the tissue through supporting the overlying epithelium. However, research into matrix biology revealed a vital role for the ECM, in particular the basement membrane, in regulating epithelial

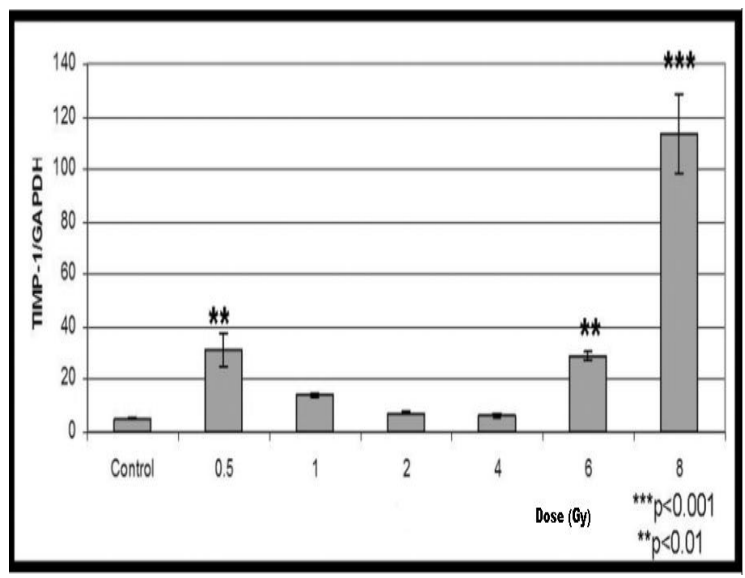

Figure 3b. Levels of TIMP-1 after different doses of RT. In 0.5, 6 and 8 Gy groups the levels of TIMP-1 increased significantly ( $p$ values were $0.01,0.01$ and 0.001 respectively). 


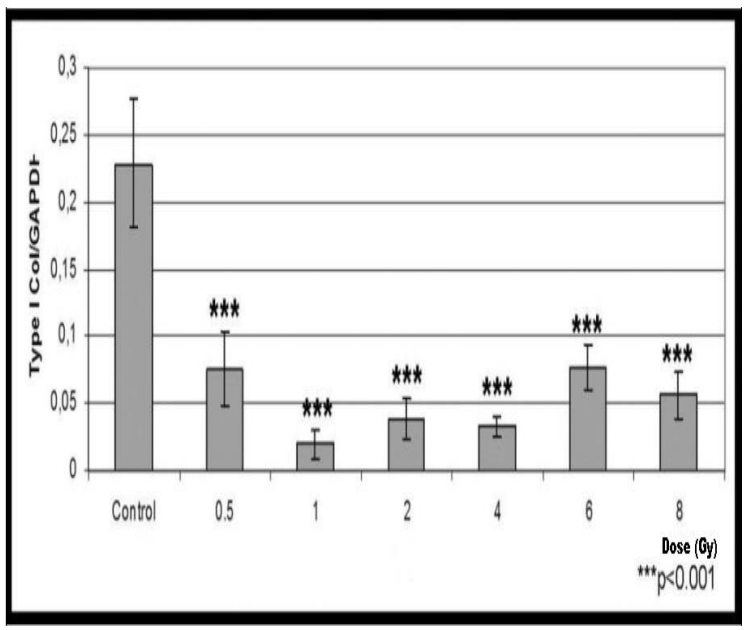

Figure 3c. Levels of Type I Col after different doses of RT. In all groups the levels of type I Col decreased significantly compared with the control group $(p<0.001)$.

kinetics. ${ }^{11,12} \mathrm{ECM}$ is produced by gingival fibroblasts. Beside producing and modifying ECM, gingival fibroblasts secrete a variety of immunoregulatory cytokines and chemical mediators upon stimulation with physiological and pathological impulse. Therefore gingival fibroblasts should have an important role in radiation-induced oral mucositis.

It is well known that ionizing radiation can cause DNA damage by direct deposition of energy and also indirectly by ionization of water molecules to produce hydroxyl radicals that can attack DNA. As a result ionizing radiation leads to DNA double-strand breaks in cells. These breaks can cause serious problems. A single break in a key gene can kill a cell, or cause it to kill itself by apoptosis. In normal condition, cells have powerful methods to repair this damage as soon as it happens. However; RT overwhelms this natural repair system, using high doses of radiation to fragment the DNA in cancer cells. ${ }^{13}$ Durner and colleagues evaluated the double-strand breaks in HGF after ionizing radiation. ${ }^{14}$ They found that, irradiation of HGF with up to 1.5 Gy showed no significant difference in DNA strand breaks whereas irradiation with $>1.5$ Gy caused a significant increase in single- stranded DNA compared to controls. An irradiation with 4 Gy resulted in unwinding of $63.7 \%$ DNA in HGF on the other hand unirradiated controls of HGF showed DNA unwinding at $38.6 \%$. This study also demonstrated the radiation response of the gingival fibroblasts is elevated in a dose dependent manner and even single dose of radiation may lead severe damage in the gingival fibroblasts.

In the current study we chose to investigate the effects of different doses of ionizing radiation $(0.5 \mathrm{~Gy}$, $1 \mathrm{~Gy}, 2 \mathrm{~Gy}, 4 \mathrm{~Gy}, 6 \mathrm{~Gy}$, and $8 \mathrm{~Gy}$ ) which were previously used in similar studies. 14, 15 Our results suggested that ionizing radiation decreased cell proliferation in all doses at 24 hours of RT when compared to control group. However we did not observe morphological change in normal spindle shape of gingival fibroblasts. This finding may be due to that; we used single fractionation of RT and we observed the cell proliferation 24 hours after radiation treatment.

Our findings revealed that the expressions of IL-1B, IL-6 and IL-8 mRNA transcripts from gingival fibroblasts increased only in 8 Gy group. It has been well established that radiation is capable of initiating a cascade of pro-inflammatory cytokines, such as IL1 ßand TNF- $3 .{ }^{16}$ Although earlier studies reported that increased levels of both cytokines were associated with non-hematologic toxicities with chemotherapy. ${ }^{17,18}$ Sonis and colleagues showed that local tissue levels of IL- $1 \beta$ and TNF- $\beta$ rose following radiation and increased in parallel to development of mucositis. ${ }^{16}$ These signaling molecules also participate in a positive-feedback loop that amplifies the original effects of anti-cancer therapy. For example, TNF- $\beta$ activates nuclear factor-KB (NF-KB) and sphingomyelinase activity in the mucosa which leads direct or indirect damages to epithelial stem cells result in a loss of renewal capacity. ${ }^{19}$

MMPs are a group of zinc-dependent endopeptidases. They were originally described as cleaving ECM components with a predominant role in ECM homeostasis. MMPs have been shown to function in several of the pathways which are known to be up-regulated in mucositis and contribute the tissue injury and inflammation in many pathological conditions.20, 21 MMP activity is regulated by TIMPs. TIMPs are the endogenous inhibitors of MMPs. TIMPs are produced by the same cell types which secrete MMPs; including macrophages, neutrophils, fibroblasts and epithelial cells. ${ }^{22,23}$ In the current study we observed that the expressions of MMP-1 and TIMP-1 mRNA transcripts from gingival fibroblasts increased in both 0.5 Gy and 8 Gy. TIMP-1 mRNA levels were also increased in 6 Gy group. We did not expect to see any increase in 0.5 Gy group; however low dose irradiation might have stimulated the MMP-1 and TIMP-1 secretion from the gingival fibroblasts. 
After 24 hours of RT, we observed that type I Col mRNA expression was suppressed in all groups. Type I Col is well known substrate of MMP-1. It has been established that MMP-1, also known as tissue collagenase, cleaves type I Col, II and III. ${ }^{24,25}$ Type I Col is a component of ECM; its decrement may be related to damage in ECM. It supports the mechanism of the mucositis started by pro-inflammatory cytokines and MMPs.

Colley et al studied the effects of radiation on the viability and cytokine production of oral epithelial cells, fibroblasts and endothelial cells. ${ }^{26}$ They used monolayer cultures of normal oral keratinocytes, normal oral fibroblasts and human dermal microvascular endothelial cells in a tissue-engineered oral mucosa (TOEM) model. Their results suggested that when compared to non-irradiated cells, the viability of all monolayer and co-cultures was significantly reduced 72 hours after irradiation while levels of secreted IL-6 and CXCL 8 were increased. On the other hand by 21 days post-irradiation the levels of secreted IL- 6 and CXCL8 were significantly reduced in irradiated when compared to non-irradiated TOEM cells. In our study we demonstrated that ionizing irradiation decreased cell proliferation. Moreover we observed significant up-regulations of IL-1, IL-6 and IL-8 in the 8 Gy RT group. Different from the study by Colley and colleagues we used lower doses of irradiation and evaluated the cytokine expressions in gingival fibroblasts at 24 hours of RT.

Our study has limitations that deserve mention. First of all, 24 hours post-irradiation period may not be enough to evaluate the differences in cytokine expressions in gingival fibroblasts. Colley and colleagues measured the cell damage and cytokine release in TOEM model up to 21 days of RT. ${ }^{26}$ They demonstrated that the expressions of the cytokines changed during time. Secondly in the literature there are some studies using higher doses of RT; however the authors stated that similar results were obtained for cell cultures treated with lower doses. ${ }^{26}$ Additionally we used increasing doses of irradiation in order to define the effect of different doses on the behavior of gingival fibroblasts.

In conclusion our results suggested that ionizing radiation, even in a single dose regulates behavior of gingival fibroblasts. Radiation-induced inflammatory characteristics of gingival fibroblasts could potentially lead to a disruption of oral mucosa. Results of this study may help to clarify the role of the gingival fibroblasts in radiation-induced oral mucositis.

\section{REFERENCES}

1. Rao Naidu MU, Ramana GV, Rani PU, et al. ChemotherapyInduced and/or Radiation Therapy Induced Oral MucositisComplicating the Treatment of Cancer. Neoplasia 6: 423-431, 2004.

2. Ps SK, Balan A, Sankar A, Bose T. Radiation induced oral mucositis. Indian J Palliat Care 15: 95-102, 2009.

3. Sonis S.T. Oral mucositis, Anticancer Drugs 22: 607-612, 2011.

4. Sonis ST. The pathobiology of mucositis, Nat Rev Cancer 4: 77-284, 2004.

5. Sonis ST. Mucositis: the impact, biology and therapeutic opportunities of oral mucositis. Oral Oncol 45: 1015-1020, 2009.

6. Wong PL, Ohura K. Porphyromonas gingivalis lipopolysaccharide signalling in gingival fibroblasts-CD14 and toll-like receptors. Crit Rev Oral Biol Med 13: 132-142, 2002.

7. Hassell TM. Tissue and cells of the periodontium. Periodontology 3: 9-38, 2003.

8. Hefti AF. Aspects of cell biology of the normal periodontium. Periodontology 3: 64-75, 2000.

9. Murakami S., Okada H. Cytokine expression in periodontal health and disease. Crit Rev Oral Biol Med 9: 284-266, 1998.

10. Epstein JB, Gorsky M, Guglietta A, et al. The correlation between epidermal growth factor levels in saliva and the severity of oral mucositis during oropharyngeal radiation therapy. Cancer 89: 2258-2265, 2000.

11. Beaulieu J. Extracellular matrix components and integrins in relationship to human intestinal epithelial cell differentiation. Prog Histochem Cytochem 31: 1-78, 1997.

12. Yurchenco P, Schittny J. Molecular architecture of basement membranes. FASEB J 4: 1577-1590, 1990.

13. Goodsell DS. The molecular perspective: double-stranded DNA breaks. Oncologist 10: 361-362, 2005.

14. Durner J, Debiak M, Bürkle A, et al. Induction of DNA strand breaks by dental composite components compared to X-ray exposure in human gingival fibroblasts. Arch Toxicol 85: 143148, 2011.

15. Wagner-Ecker M, Schwager C, Wirkner U, et al. MicroRNA expression after ionizing radiation in human endothelial cells. Radiat Oncol 5: 25-35, 2010.

16. Sonis ST, Peterson RL, Edwards LJ, et al. Defining mechanism of action of interleukin-11 on the progression of radiationinduced oral mucositis in hamsters. Oral Oncol 36: 373-381, 2000.

17. Hall PD, Benko H, Hogan KR, Stuart RK. The influence of serum tumour necrosis factor-alpha and interleukin-6 concentrations on non-hematologic recovery in patients with acute myelogenous leukemia. Exp Hematol 23: 1256-60, 1995. 
International Journal of Hematology and Oncology

18. Sleijfer S, Vujaskovic Z, Limburg PC, et al. Induction of tumour necrosis factor-alpha as a cause of bleomycin-related toxicity. Cancer 82: 970-974, 1998.

19. Gibson RJ, Bowen JM, Cummins AG, et al. Ultrastructural changes occur early within the oral mucosa following cancer chemotherapy (abstract A-373), Support Care Cancer 12: 389, 2004.

20. Al-Dasoogi N, Gibson RJ, Bowen JM, Kefe D. Matrix metalloproteinases: key regulators in the pathogenesis of chemotherapy-induced mucositis? Cancer Chemother Pharmacol 64: 1-9, 2009.

21. Sengupta N, MacDonald T. The role of matrix metalloproteinases in stromal/epithelial interactions in the gut. Physiology 22: 401-409, 2007.

22. Pender S, MacDonald T. Matrix metalloproteinase's and the gut-new roles for old enzymes. Curr Opin Pharmacol 4: 546550, 2004.

23. Gill S, Parks W. Metalloproteinases and their inhibitors: regulators of wound healing, Int J Biochem Cell Biol 40: 1334-1347, 2007.

24. Sato H, Takino T. Coordinate action of membrane-type matrix metalloproteinase-1 (MT1-MMP) and MMP-2 enhances pericellular proteolysis and invasion. Cancer Sci 101: 843-847, 2010.

25. Eiko Ohuchi E, Imai K, Fujiii Y, et al. Membrane Type 1 Matrix Metalloproteinase Digests Interstitial Collagens and Other Extracellular Matrix Macromolecules. J Biol Chem 272: 24462451, 1997.

26. Colley HE, Eves PC, Pinnock A, et al. Tissue-engineered oral mucosa to study radiotherapy-induced oral mucositis. Int J Radiat Biol 89: 907-914, 2013.

\section{Correspondence}

Dr. Guler YAVAŞ

Selçuk Üniversitesi Tıp Fakültesi

Radyasyon Onkolojisi Anabilim Dalı

42075 KONYA / TURKEY

Tel: (+90.332) 2244085

Fax: (+90.332) 2416065

e-mail: guler.aydinyavas@gmail.com 